\title{
Tanggung Jawab Media kepada Masyarakat Pada Pemberitaan Kasus Ledakan Bom Di Hotel J.W Marriot Dan Ritz Carlton
}

\author{
Eka Prabowo Putra \\ Program Studi Ilmu Komunikasi Fakultas Ilmu Sosial Ilmu Politik \\ UPN "Veteran" Yogyakarta \\ Jl. Babarsari No. 2 Tambakbayan Yogyakarta 55282, Telp. (0274) 485268 \\ email: ekaprabowo@gmail.com
}

\begin{abstract}
On July 17, 2009 Indonesia rocked by bomb blasts that occurred at the Ritz Carlton and JW Marriott. Bomb explosion which occurred one day before the Manchester United team was staying at the Ritz Carlton hotel that killed eight people and injuring 53 people. High-powered bombs at the Ritz Carlton and JW Marriot reap harsh criticism from the international community, including from Australia, the United States, European Union, the United Kingdom, France, New Zealand, Japan and member countries ASEAN. This research aims to know the contents publicity about the case of JW Marriot Hotel bomb blast and the Ritz Carlton in SKH Compass July-September period of 2009. The method used is content analysis. Content analysis is a research method to describe objectively, systematically, and quantitatively. The population in this study is the news bomb blast at Hotel JW Marriot and Ritz Carlton at SKH Compass July-September period of 2009. This research uses total sampling technique with a total 47 news story. Categories used in this study is the dimension of news, sources, news orientation, type of coverage, the nature of news, news position, type of news, factgathering techniques, themes, news, and trend news. The results showed that the dimensions of news which are widely used combinations of political-legal dimension. Speakers who often bring up is a combination of the Government of Indonesia with a witness. Type of coverage that is widely used types of two-sided coverage by the news of psychological orientation. Types used in straight news story with a combination of fact-gathering techniques-observation interview. The nature of news is informative. Category of news themes are often depicted the process of finding the perpetrator. Trends news presented is neutral.
\end{abstract}

Keywords: Content Analysis; Media Responsibility; JW Marriot and Ritz Carlton Bombs; SKH Kompas

\begin{abstract}
Abstrak
17 Juli 2009 Indonesia diguncang oleh ledakan bom yang terjadi di Ritz Carlton dan JW Marriott. Ledakan bom yang terjadi sehari sebelum tim Manchester United menginap di Hotel Ritz Carlton yang menewaskan delapan orang dan melukai 53 orang. Bom bertenaga tinggi di Ritz Carlton dan JW Marriot menuai kritik keras dari masyarakat internasional, termasuk dari Australia, Amerika Serikat, Uni Eropa, Inggris, Prancis, Selandia Baru, Jepang dan negara-negara anggota ASEAN. Penelitian ini bertujuan untuk mengetahui isi publisitas tentang kasus ledakan bom JW Marriot Hotel dan Ritz Carlton di SKH Compass periode JuliSeptember 2009. Metode yang digunakan adalah analisis konten. Analisis konten adalah metode penelitian untuk menggambarkan secara objektif, sistematis, dan kuantitatif. Populasi dalam penelitian ini adalah ledakan bom berita di Hotel JW Marriot dan Ritz Carlton di SKH Compass periode Juli-September 2009. Penelitian ini menggunakan teknik pengambilan sampel total dengan total 47 berita. Kategori yang digunakan dalam penelitian ini adalah dimensi berita, sumber, orientasi berita, jenis liputan, sifat berita, posisi berita, jenis berita, teknik pengumpulan fakta, tema, berita, dan berita tren. Hasil penelitian menunjukkan bahwa dimensi berita yang banyak digunakan adalah kombinasi dimensi politik-hukum. Pembicara yang sering muncul adalah kombinasi dari Pemerintah Indonesia dengan saksi. Jenis cakupan yang banyak digunakan jenis cakupan dua sisi oleh berita orientasi psikologis. Jenis yang digunakan dalam berita lurus dengan kombinasi teknik pengumpulan fakta-pengamatan wawancara. Sifat berita informatif. Kategori tema berita sering tergambar proses menemukan pelaku. Tren berita yang disajikan adalah netral.
\end{abstract}

Kata kunci: Analisis Isi; Tanggung Jawab Media; Bom JW Marriot dan Ritz Carlton; SKH Kompas 


\section{Pendahuluan}

Teror mengandung arti penggunaan kekerasan, untuk menciptakan atau mengkondisikan sebuah iklim ketakutan di dalam kelompok masyarakat yang lebih luas, dari pada hanya pada jatuhnya korban kekerasan. Publikasi media massa adalah salah satu tujuan dari aksi kekerasan dari suatu aksi teror, sehigga pelaku merasa sukses jika kekerasan dalam terorisme serta akibatnya dipublikasikan secara luas di mass media (Piliang, 2004 dalam buku hendropriyono). Dalam perkembangannya lalu muncul suatu konsep yang memberi pengertian, bahwa terorisme adalah cara atau teknik intimidasi dengan sasaran sistematik, demi suatu kepentingan politik tertentu.

Whittaker (2003) dalam buku Hendropriyono mengutipbeberapapengertianterorismeantaralain menurut Walter Reich yang menyatakan, bahwa terorisme adalah a strategy of violence designed to promote desired outcomes by instilling fear in the public at large (suatu strategi kekerasan yang dirancang untuk meningkatkan hasil-hasil yang diinginkan, dengan cara menanamkan ketakutan di kalangan masyarakat umum). Terorisme adalah the use or threaten use of force designed to bring about political change (penggunaan atau ancaman penggunaan kekerasan, yang bertujuan untuk mencapai terjadinya perubahan politik) (Brians Jenkins, 1974:1999:2006 dalam buku Hendropriyono). (Hendropriyono, 2009: 25).

Kebangkitan yang paling mutakhir dalam terorisme keagamaan sebagian besar diidentifikasikan dengan tren-tren yang berlangsung dalam dunia Muslim dan Arab, kebanyakan pada penyesalan dari para pembela islam dan kaum Islamis di Barat dan Timur. Menurut mereka, kebangkitan dari agama fundamentalis adalah sebuah fenomena yang mendunia, yang cukup benar, dan kebanyakan penganut dalam Islam fundamentalis bukanlah para teroris, yang juga benar. Lebih jauh lagi, Barat membutuhkan gambaran dari sebuah musuh setelah berakhirnya perang dingin, dan Islam untuk berbagai peranan telah mengisi peranan tersebut. Mereka menyatakan bahwa Islam adalah sebuah agama yang secara moral sangat tinggi, lebih mendukung cinta dan bukan kebencian, serta pluralis, dan demokratis dalam inspirasinya. Karena pembelaan yang terlalu bersemangat ini, menjadi sesuatu yang nyaris tabu untuk membicarakan terorisme dalam konteks Islam.

Persepsi yang populer di antara orang-orang Barat adalah menyamakan Islam radikal dengan terorisme. Sementara banyak kaum fundamentalis yang tidak mendukung terorisme, persepsi tersebut masih lebih akurat dibanding pemaafan yang mengklaim bahwa ketakutan-ketakutan orang Barat dalam karakter sebetulnya "mitos", berdasar pada kecemasan-kecemasan yang tidak mendasar, prasangka, dan pengetahuan yang tidak memadaimengenaiIslam.(Laquer,2005:167-170)

Berbagai ulasan yang terkait dengan terorisme tersebut tidak lepas dari liputan media yang memberitakan soal terorisme dalam berbagai aspek. Sebagian kalangan mengkritik dan menganggap media massa telah mengeksploitasi berbagai tayangan terorisme.

Hubungan antara media dan terorisme diungkap lebih lanjut oleh Weiviorla (1993) dalam Surat Kabar Pikiran Rakyat yang menjabarkan empat hubungan. Pertama, pure indifference, yaitu teroris tidak hendak menakut-nakuti kelompok populasi sasaran di luar korban-korban mereka ataupun tidak hendak merealisasikan kudeta propaganda melalui aksi terorisme mereka

Kedua, relative indifference, yaitu kekerasan tidak semata-mata berorientasi pada media. Tujuannya tidak untuk mempertontonkan aksi atau menarik perhatian media massa.

Ketiga, media-oriented strategy, yaitu tindakan terorisme merupakan hasil perhitungan matang mengenai perilaku media massa. Komunike-komunike dari terorisme itu dirancang secara cermat dan aktivitas mereka diprogram agar mengandung karakteristik-karakteristik yang memang sesuai dengan beragam media. Pada tingkat taktik mereka bermain-main dengan kebingungan di kalangan masyarakat atau pemerintah. 
Keempat, a total break with the broader community. Dalam hal ini jurnalis menjadi musuh teroris. Bagi para teroris, ketika era dunia telah menjadi era media massa, tindakan mereka seperti mendapat kendaraan yang tepat. Terlebih ketika teror memang merupakan pesan yang harus tersebar luas secara massif. Kendaraan yang paling mampu mendistribusikan pesan itu adalah media massa (Pikiran Rakyat, 2009).

Pada tanggal 17 Juli 2009 Indonesia diguncang ledakan bom yang terjadi di hotel Ritz Carlton dan JW Marriot. Ledakan bom yang terjadi satu hari sebelum tim Manchester United menginap di hotel Ritz Carlton itu menewaskan 8 orang dan melukai 53 orang. Diantara orang yang menjadi korban adalah Timothy D Mackay asal Selandia Baru (Presiden Direktur PT holcim Indonesia). Dari olah tempat kejadian perkara dipastikan dua bom rakitan meledak dan satu bom aktif yang belum sempat diledakkan ditemukan di kamar 1808 Hotel Marriott.

Ledakan bom berkekuatan tinggi di hotel Ritz Carlton dan JW Marriot menuai kecaman keras dari komunitas internasional, anatara lain dari Australia, Amerika Serikat, Uni Eropa, Inggris, Perancis, Selandia Baru, Jepang, dan negara anggota ASEAN.

Disini media khususnya SKH Kompas sebagai surat kabar berskala nasional memiliki tanggung jawab sosial untuk memberitakan mengenai perkembangan kasus ledakan bom Hotel J.W Marriot dan Ritz Carlton. Media massa berfungsi sebagai media komunikasi bnagi masyarakat harus melaksanakan tugasnya untuk memberitakan berdasarkan fakta yang sesungguhnya terjadi di lapangan. Dalam dunia jurnalistik, surat kabar diasumsikan sebagai pelapor untuk melaporkan peristiwa yang belum diketahui masyarakat dengan netral. Berdasarkan fungsi yang dimiliki surat kabar, yaitu informasi, edukasi, hiburan, persuasif, dan alat kontrol sosial dapat disimpulkan bahwa penyebaran informasi merupakan fungsi utama surat kabar. Dari penjelasan di atas, ingin diteliti bagaimana isi pemberitaan tentang kasus ledakan bom Hotel J.W Marriot dan Ritz Carlton di SKH Kompas mengenai perkembangan kasus tersebut dan tindakan dari pemerintah.

Teori Tanggung Jawab Sosial ini lahir dari ketidakpuasan terhadap teori liberal yang melahirkan banyak penyimpangan dari kebebasan yang "keblabasan". Teori ini lahir dari pemikiran para ahli yang lebih mengedepankan persoalan etika dan tanggung jawab dalam kebebasan.. Teori ini berkembang di AS dan Inggris pada pertengahan abad 19 dan banyak diminati negara-negara penganut demokrasi hingga saat ini. Terbentuknya Komisi Kebebasan Pers di AS setelah Perang Dunia II ikut mendorong lahirnya teori ini. Dasar berfikirnya, kebebasan pers perlu diatur dan diharuskan memiliki tanggung jawab melalui kesepakatan pemerintah dengan masyarakat dan pers berdasarkan konstitusi. (Afifi, 2004 : 13)

Teori tanggung jawab sosial dapat diterapkan secara luas, karena teori tersebut meliput beberapa jenis media cetak privat dan lembaga siaran publik, yang dapat dipertanggungjawabkan melalui berbagai bentuk prosedur demokratis pada masyarakat. Pemilikan dan pengendalian media hendaknya dipandang sebagai jenis pekerjaan pengurusan, bukan sebagai hak perdata, dan ada pergeseran nyata yang menjauh dari relativisme karakteristik dasar teori kebebasan pers dan dari optimisme bahwa "pasar bebas gagasan" benar-benar dapat memenuhi tuntutan masalah individual dan sosial untuk kepentingan sendiri.

Dapat dilihat bahwa teori tanggungjawab sosial harus berusaha mengawinkan tiga prinsip yang agak berbeda: prinsip kebebasan dan pilihan individual; prinsip kebebasan media; dan prinsip kewajiban media terhadap masyarakat. Ciri lembaga publik baru untuk siaran yang paling memiliki andil dalam merajuk ketiga prinsip di atas adalah penekanannya pada kenetralan dan keseimbangan dalam hubungannya dengan pemeintah dan hal-hal yang menyangkut kontroversi masyarakat dan pencakupan 
mekanisme untuk meningkatkan daya tanggap media yang relevan terhadap tuntutan audiensnya serta bertanggungjawab kepada mayarakat atas aktivitas yang dilakukan (McQuail, 1987:116).

Prinsip utama teori tanggung jawab sosial, adalah, 1. Media seyogyanya menerima dan memenuhi kewajiban tertentu kepada masyarakat; 2. Kewajiban-kewajiban tersebut terutama dipenuhi dengan menetapkan standar yang tinggi atauprofesionaltentangkeinformasian,kebenaran, ketepatan, obyektifitas, dan keseimbangan; 3. Dalam menerima dan menerapkan kewajiban tersebut, media seyogyanya dapat mengatur diri sendiri di dalam kerangka hukum dan lembaga yang ada; 4. Media seyogyanya menghindari segala sesuatu yang mungkin menimbyulkan kejahatan, kerusakan atau ketidaktertiban umum atau penghinaan terhadap minoritas etnik atau agama; 5. Media secara keseluruhan hendaknya bersifat pluralis dan mencerminkan kebhinekaan masyarakatnya, dengan memberikan kesempatan yang sama untuk mengungkapkan berbagai sudut pandang dan hak untuk menjawab; 6. Masyarakat dan publik, berdasarkan prinsip yang disebut perama, memiliki hak untuk mengharapkan standar prestasi yang tinggi dan intervensi dapat dibenarkan untuk mengamankan kepentingan umum; 7. Wartawan dan media professional seyogyanya bertanggung jawab terhadap masyarakat dan juga kepada majikan serta pasar (McQuail, 1987: 117).

Pada sebuah media, dalam menyajikan sebuah berita tidak hanya kecepatan, ketrampilan dan keakuratan yang dibutuhkan. Akan tetapi, kejujuran dan kenetralan juga diperlukan karena disini terlihat tanggung jawab media dan wartawan terhadap masyarakat.

Terorisme dan media memang punya kaitan mutualisme yang sangat erat. Tidak jauh berbeda dengan teroris tempo dulu, teroris masa kini juga, bahkan sangat memerlukan publisitas dalam melakukan aksi terornya. Tujuan teror bisa bermacam-macam, antara lain untuk memperoleh perhatian, mendemonstrasikan kemampuannya, merongrong dan merusak citra suatu pemerintahan, menebarkan ketakutan, atau untuk menarik dukungan terhadap perjuangan mereka. Tanpa publisitas dari media, aksi teror mereka tidak akan "berbunyi" atau "bergema". Dalam tulisannya, Effendi Gazali pun sepakat dengan menyebutkan tanpa media massa terorisme tidak akan ada. Tentunya yang dimaksudkan bukan wujud pelakunya akan tetapi dampak dari aksi terror terhadap masyarakat, pemerintah atau kelompok tertentu (http://politik.kompasiana. com/2010/03/08/media-mutualisme-terorisme/).

Jakob Oetama (2001) dalam buku Hendropriyono menyatakan, bahwa terorisme klasik melakukan propaganda melalui aksi (propaganda by deeds) sehingga memerlukan dukungan mass media.

Terorisme memanfaatkan maksimal para jurnalis untuk memperbesar hasil baik yang didapatkannya. Kebanyakan jurnalis tidak merasa telah membantu keberhasilan terorisme, karena liputan yang dijamin oleh kebebasan pers dalam Negara demokrasi. Kekerasan merupakan berita karena jarang terjadi, sehingga jika berita tersebut diturunkan dapat mengentakkan atau menarik perhatian publik. Sebaliknya, sesuatu keterangan bukanlah berita yang menarik, karena merupakan keadaan yang biasa dijumpai sehari-hari.

Terdapat keadaan yang saling menguntungkan antara para teroris dan media. Peliputan media telah menyediakan keuntungan konstan bagi teroris; media telah memperkuat tindakan-tindakan teroris sebagai sesuatu yang penting secara politis diluar porsi yang semestinya. Para teroris selalu mengerti betapa pentingnya memanipulasi media, karena keberhasilan terorisme sangat ditentukan oleh peran mass media nasional dan internasional, yang berfungsi menyebarkan kejadian walau sangat mengerikan dengan bebas tanpa batas. 
Secara tendensius hal tersebut terjadi di negara-negara liberal demokrasi, yang kacau dalam membedakan antara kebebasan (politik etis) dengan penelanjangan (politik porno) (Hendropriyono, 2009:217).

Teroris membutuhkan media untuk mendukung kegiatannya. Peliputan media secara luas merupakan salah satu indicator keberhasilan teroris. Brian Jenkis (1974) menyebut "terorisme adalah teater".

Paraterorisinginmeraihperhatianpemerintah, public dan dunia internasional melalui liputan media untuk mendukung tujuannya. Pada tingkatan ini, sebenarnya media massa menghadapi posisi yang dilematis. Tidak mengekspos suatu aktifitas terorisme barangkali disebut sebagai tidak sensitive terhadap hal-hal penting dan aktual. Terlalu mengekpos aktifitas teroris pun akan memperoleh kecaman tertentu dan pihak lainnya.

Ada delapan penggunaan media secara aktif, antara lain, 1. Mengkomunikasikan pesan-pesan ketakutan kepada khalayak luas; 2. Mempolarisasi pendapat umum; 3. Mencoba menarik anggota baru pada gerakan teroris; 4. Mengecoh musuhnya dengan menyebar informasi palsu; 5. Mengiklankan diri dan membuat mereka terwakili; 6. Membangkitkan keprihatinan public terhadap korban untuk menekan agar pemerintah melakukan kompromi atau konsesi; 7. Mengalihkan perhatian publik dari isu-isu yang tidak dikehendaki dengan harapan berita teror mereka mengisi halaman depan media; 8. Membangkitkan kekecewaan publik terhadap pemerintah.

Ada enam penggunaan media secara pasif oleh teroris, diantaranya, 1. Sebagai jaringan komunikasi eksternal di antara teroris; 2. Mempelajari teknik-teknik penanganan terbaru terhadap terorisme dari laporan media; 3. Mendapat informasi tentang kegiatan terkini tentang pasukan keamanan menghadapi teror yang sedang mereka lakukan; 4. Menikmati laporan media yang berlebihan tentang kekuatan teroris hingga menciptakan ketakutan pihak musuh dan mencegah keberanian polisi secara individual; 5. Mengidentifikasi target-target selanjutnya; 6. Mencari tahu reaksi public terhadap tindakan mereka.
Disisi lain, setidaknya ada empat alasan mengapa media ikut memanfaatkan peristiwa terorisme. 1. Kejahatan selalu merupakan goodnews bila perhatian utama hanya menjual koran atau program televisi; 2. Media membawa banyak berita dengan kandungan kekerasan karena merasa public memintanya agar menjadi tahu persis tentang aspek-aspek kehidupan yang mengancam mereka; 3. Kehidupan khalayak yang membosankan karena disiksa rutinitas tidr, berangkat dan bekerja, membutuhkan berita-berita kekerasan; 4. Kadangkala ada sekelompok orang yang menyatakan simpati pada tujuan teroris, dan media mengeksposnya karena menganggapnya unik atau demi covering both sides. (Susilastuti dkk, $2006: 25$ ).

Tujuan prinsip yang ingin dicapai kelompok teroris adalah pajanan media secara maksimal (the maksimum media eksposure). Melihat tujuan ini maka pada dasarnya media akan memanfaatkan aksi terorisme untuk kepentingan pemberitaan. Di sisi lain, terorisme memanfaatkan media untuk menunjukkan eksistensinya kepada pihakpihak yang dituju. (Susilastuti dkk, 2006 : 27).

\section{Metode Penelitian}

Jenis penelitian yang dipakai dalam penelitian ini adalah dengan cara melihat fakta media dengan menggunakan metode penelitian kuantitatif dengan jenis analisis isi (content analysis). Analisis isi adalah suatu metode penelitian untuk mendeskripsikan secara obyektif, sistematis, dan kuantitatif isi komunikasi yang tampak (Krippendorff, 1993 : 10). Konsep dasar tentang analisis isi, yaitu, 1. Data sebagaimana yang dikonsumsikan kepada analisis;2. Konteks data; 3. Bagaimana pengetahuan analisis membatasi realitasnya;4. Target analisis isi; 5. Referensi sebagai tugas intelektual yang mendasar. 6. Kesamaan sebagai kriteria akhir keberhasilan. (Krippendorf, 1993: 23)

Penelitian ini menggunakan metode analisis isi dengan membuat inferensi-inferensi yang dapat ditiru (replicable) dan sahih data dengan memperhatikan konteksnya (Krippendorff, 1003: 131). Dengan demikian diperoleh keterangan dari isi pesan yang disajikan dalam media massa, surat kabar khususnya. 
Studi ini memeriksa berita-berita jurnalistik tentang kasus ledakan bom Hotel J.W Marriot dan Ritz Carlton di SKH Kompas periode JuliSeptember 2009. Pada penelitian ini, berita-berita tersebut diteliti dan dimasukkan ke dalam proses pengkodingan.Periode bulan Juli-September 2009 karena pada bulan tersebut kasus tersebut muncul.

Populasi dalam penelitian dengan menggunakan metode analisis isi ini adalah SKH Kompas. Alasan mengambil SKH Kompas dalam penelitian ini karena pemberitaan mengenai kasus bom J.W Marriot dan Ritz Carlton paling banyak muncul di media tersebut. Teknik pengumpulan data yang digunakan dalam penelitian ini adalah teknik dokumentasi, yaitu dengan mengumpulkan berita kasus ledakan bom Hotel J.W Marriot dan Ritz Carlton di SKH Kompas periode Juli-September 2009. Analisa data diperoleh secara langsung (textual) yang dimasukan dalam lembaran coding sheet yang membuat unit-unit analisis \& kategorisasi. Data yang digunakan dalam mengolah data dari cooding sheet analisa dipakai untuk menjawab pertanyaan dalam rumusan masalah. Coding merupakan proses dimana data mentah secara kemudian disusun ke dalam unit-unit yang memungkinkan membuat deskripsi karakteristik isi yang valid.

Tabel 1. Unit Analisis dan Kategori

\begin{tabular}{|c|c|c|c|}
\hline No. & Unit Analisis & Katcgori & Sub Katcgori \\
\hline 1. & Media & SKII Kompas & \\
\hline 2. & Dimensi. & $\begin{array}{l}\text { Fkonomi, Sosial, Kesehatar, } \\
\text { Hukum, Politik, Olahraga, } \\
\text { Kombinasi }\end{array}$ & \\
\hline 3. & Narasumber. & $\begin{array}{l}\text { Pemerintah lndonesia } \\
\text { Pemerinlah Australia } \\
\text { Pcmerintah Amerika } \\
\text { Pemerintah Inggris } \\
\text { Pemerinlah Perancis } \\
\text { Tim Manclester Utrited } \\
\text { Iivent Organizer, Saksi, } \\
\text { Korban, Pakar, Psikolog, } \\
\text { Kombinasi, I ain-lain }\end{array}$ & \\
\hline 4. & Oricntasi Berita. & $\begin{array}{l}\text { Psikologis, Sosiologis, } \\
\text { Psikologis - Sosiologis. }\end{array}$ & \\
\hline 5. & Típe Liputan. & Satu Sisi, Dua Sisi, Multi Side & \\
\hline 6. & Silâl Berila. & $\begin{array}{l}\text { Persuasiץ, Argumentalif' } \\
\text { Deskriptif, Informatif, } \\
\text { Persuasif - Argumentatif } \\
\text { Persuasif - Informatif }\end{array}$ & \\
\hline 7. & Pusisi Berita & $\begin{array}{l}\text { Halaman Depan, Halaman } \\
\text { Jengah }\end{array}$ & \\
\hline 8. & Jenis Berita. & $\begin{array}{l}\text { Straight Ncws,Soft News, } \\
\text { Feature, Indepth Reporting }\end{array}$ & \\
\hline 9. & $\begin{array}{l}\text { Teknik } \\
\text { Pengumpulan } \\
\text { Fakta. }\end{array}$ & $\begin{array}{l}\text { Wawancara, Observasi, } \\
\text { Kombinasi }\end{array}$ & \\
\hline 10. & Tema & Tindakan P'emerintalı. & $\begin{array}{l}\text { Perang melawan terorisme, Alurat } \\
\text { hukum penberantasan terorisme, } \\
\text { Melibatkan TNI dalam pençaan } \\
\text { terorisme }\end{array}$ \\
\hline
\end{tabular}


Proses Pemeriksaan.

Dampak Pengeboman.

Korban bon.

Penembakan teroris di

Temanggung

Penembakan teroris di Solo
Tiga orang tak terbukti sebagai

pendana; Pemeriksaan mertua

Noordin M Top: Pcmeriksaan Arina

yang di duga Noordin M Top;

Pemeriksam DNA korban

penyergapan di T'enranggung;

Jbrohim korban penyergapan di

Temanggung: Pemeriksaan tehadap

Jibril.

M.U batal main di Indoncsia; Pelaku ekonomi khawatir; Kecaman keras dari negara lain; Perekononian relatif tenang; Pengamanan SBY ditingkatkan; Pengawasan berlebihat terhadap pesantren.

Warga negara asing: Warga

lndonesia; Kombinasi

Penyergapan teroris yang di duga

Noordin M Top: lerorisme tumbuh

di Jateng

Baku tembak dengan teroris yang $\mathrm{di}$ duga Noordin M Iop; INA Noordin sudah terbukti

\section{Kecenderungatı Memperlajam, Netral,} Berita

Mcredakan

Sumber: Ilasil olah data pencliti

Reliabilitas merupakan ukuran kapasitas data-data yang digunakan dalam proses penelitian untuk memenuhi tingkat obyek tertentu. Untuk melakukan suatu interpretasi relibility dapat dilakukan dengan menggunakan data minimal dalam bentuk prosentase pada tingkat kesamaannya formula yang dipakai.

$$
\mathrm{CR}: \frac{2 m}{N 1+N 2}
$$

\section{CR: Coeficient Realibility}

$\mathrm{M}$ : Jumlah pernyataan yang disetujui oleh pengkode, N1 dan N2.

N1 : Pengkode / kode 1

N2 : Pengkode / kode 2
Validitas digunakan untuk mengetahui kesamaan antara data yang terkumpul dengan data sesungguhnya terjadi pada obyek yang diteliti, sehingga dapat diperoleh hasil penelitian yang valid. Instrumen yang valid alat ukur yang digunakan untuk mendapatkan data valid. Valid berarti instrumen tersebut digunakan untuk mnegukur apa yang seharusnya diukur.

Pengujian validitas dimaksudkan untuk menguji ketepatan item-item dalam coding sheet, apakah item-item yang ada mampu menggambarkan dan menjelaskan variabel yang diteliti. Pengujian validitas instrumen dilakukan dengan mengkorelasikan antara nilai masing-masing item dengan total item. 


\section{Hasil Penelitian dan Pembahasan}

Surat kabar mempunyai fungsi memberi informasi, mendidik, menghibur, dan mempengaruhi. Surat kabar mempunyai kelebihan dibandingkan media yang lain, antara lain terdokumentasi, lebih lengkap, dan jangkauannya lebih luas. Dalam suatu masalah atau konflik, surat kabar dapat berperan sebagai pemertajam konflik, pereda konflik, atau bersikap netral. Dalam masalah ini surat kabar berperan untuk menyampaikan informasi yang baru tentang ledakan bom di Hotel J.W Marriot dan Ritz Carlton serta penangkapan pelaku tindak terorisme.

Kasus terorisme ini mendapat perhatian yang besar dari masyarakat dunia karena korban ledakan bom banyak orang asing. Kasus mengenai terorisme tidak hanya terjadi kali ini saja, akan tetapi sudah berkali-kali. Mulai dari tahun 2000-2009, seperti kasus ledakan bom Bali I, Bom bali II, serta bom Kedubes Filiphina, dan Kedubes Malaysia.

Pada kasus ini, surat kabar menjalankan fungsinya sebagai pemberi informasi. Surat kabar terus-menerus menyajikan kasus tersebut agar mendapat perhatian lebih dari masyarakat. Sejak kasus ini mencuat, tanggung jawab sosial sebuah media diuji. Disini media diharuskan memberikan informasi yang benar mengenai kasus tersebut tanpa ditambah-tambahi maupun dikurangi kepada masyarakat dan media harus bersikap seimbang dalam menyajikan berita tersebut tidak memihak kepada salah satu pihak melainkan memihak kepada kebenaran dan keadilan. Surat kabar selalu memberitakan mengenai perkembangan dan informasi terbaru mengenai kasus tersebut. Jumlah korban, hasil-hasil penelitian, dan tindakan yang dilakukan oleh pemerintah selalu diberitakan oleh media massa tak terkecuali SKH Kompas.

Analisis terhadap isi pemberitaan kasus ledakan bom di Hotel J.W Marriot dan Ritz Carlton ini dilakukan untuk mngetahui kecenderungan pemberitaan media terhadap masalah ini. Dari uraian di atas, maka hasil penelitian analisis isi pemberitaan tentang kasus ledakan bom Hotel J.W Marriot dan Ritz Carlton di SKH Kompas periode Juli-September 2009 adalah sebagai berikut:

Dalam pemberitaan kasus ledakan bom di Hotel J.W Marriot dan Ritz Carlton pada SKH Kompas, berita tersebut banyak dimuat di halaman depan atau headline karena masalah tersebut berdampak secara internasional dan mempunyai nilai berita yang tinggi dan menjadi topik yang hangat untuk dibicarakan. SKH Kompas ingin selalu menjadikan berita tentang kasus terorisme ini sebagai topik utama karena masyarakat juga selalu menanti bagaimana perkembangan kasus ini. Selain berada di halaman depan, berita tersebut juga berada di halaman tengah yang memuat berita hukum dan politik.

\section{Tabel 2. Hasil Unit Analisi dan Kategori}

\begin{tabular}{cll} 
No & \multicolumn{1}{c}{ Unit Analisis } & \multicolumn{1}{c}{ Hasil Kategorisasi } \\
\hline 1 & Dimensi & Ilukum dan Kombinasi $36,15 \%$ \\
2 & Narasumber & Kombinasi Pemerintah-Saksi $44,67 \%$ \\
3 & Orientasi Berita & l'sikologis $51,05 \%$ \\
4 & Tipe Liputan & Dua Sisi $42,53 \%$ \\
5 & Sifat Berita & Informatif $51,04 \%$ \\
6 & Posisi Berita & Iralaman Dopan $68,07 \%$ \\
7 & Jenis Berita & Straiglh News $80,84 \%$ \\
8 & Teknik Pengumpulan Fak1a & Kombinasi $55,30 \%$ \\
9 & Tema & Proses pencarian pelalku 27,65\% \\
& Sub Kategori & Perburuan lbrohim $10,63 \%$ \\
10 & Kecenderungan Berita & Netral $55,30 \%$ \\
\hline
\end{tabular}


Berita tentang terorisme ini juga berisi tentang hukum dan politik, contohnya berita mengenai presiden SBY yang menjadi target serangan para teroris. Dalam hal ini SKH Kompas ingin menyampaikan bahwa tindakan teroris adalah melanggar hukum. Berita mengenai rencana penyerangan Persiden SBY telah digagalkan oleh Pemerintah dengan menangkap para teroris yang bersembunyi di Bekasi. Rencana penyerangannya sendiri dengan melakukan bom mobil yang pernah dilakukan pada bom bali I saat iring-iringan rombongan Presiden menuju Istana Negara. Kerja keras Polri dalam menumpas teroris membuahkan hasil, dengan menggagalkan rencana pembunuhan Presiden SBY.

Pada halaman depan ini, jenis berita yang paling sering muncul adalah straight news. Straight news adalah jenis berita yang dibuat untuk menyampaikan peristiwa-peristiwa yang penting dan harus segera diketahui oleh khalayak. Dalam kasus ini setiap hari selalu muncul informasi-informasi baru yang berhubungan dengan masalah ini. Format straight news cocok untuk menuliskan berita ini karena straight news mementingkan keaktualitasan suatu peristiwa.

Aktualitas merupakan bagian yang sangat penting dalam menyajikan sebuah berita dan persaingan antar media. Selain itu, berita adalah peristiwa yang baru atau sedang terjadi. Setiap media berlomba-lomba untuk menyajikan informasi yang paling baru agar masyarakat tertarik untuk membaca dan membeli surat kabar mereka. Keaktualitasan yang disajikan SKH Kompas menunjukkan SKH Kompas selalu update berita baru. Masyarakat yang tadinya tidak tahu menjadi tahu informasi yang baru mengenai sebuah masalah. Dalam hal ini, SKH Kompas selalu memberitakan kasus terorisme secara update, setiap harinya selalu ada berita tentang kelanjutan kasus terorisme.

Indepth reporting dibuat agar pembaca mengetahui lebih mendalam mengenai kasus ini. Disini SKH Kompas sedikit memberitakan masalah ini dalam bentuk indepth reporting padahal akan lebih menarik jika disajikan dalam bentuk indepth reporting dengan melakukan liputan mendalam tentang persembunyian para teroris atau mengangkat tentang bagaimana ajaran teroris menurut islam, karena terorisme saat ini selalu identik dengan Islam. Banyak pelaku terorisme yang berasal dari pesantrenpesantren di Indonesia, lalu mereka melanjutkan belajar di Di afganistan yang merupakan basis Al-Qaeda, salah satu kelompok teroris yang sedang di buru oleh Amerika Serikat bahkan untuk memerangi Al-Qaeda dan jaringannya ini Amerika mengalokasikan dana 40 milyar dollar AS lebih. Wartawan akan lebih merasa tertantang untuk melakukan liputan mendalam tentang terorisme, karena pelaku terorisme selalu bersembunyi dan sulit unutuk di temui. Indepth yang disajikan SKH Kompas sebenarnya dapat memaparkan orang penting dibalik kasus ledakan bom di Hotel J.W Marriot dan Ritz carlton. Selain berita straight news dan indepth reporting yang disajikan, SKH Kompas juga memberikan variasi lain dalam menyajikan berita ini yaitu dengan menyajikan berita soft news.

SKH Kompas mengemas berita terorisme dengan kombinasi dimensi. Kombinasi yang paling sering muncul adalah dimensi politikhukum. Hal ini dikarenakan ilmu hukum berkaitan dengan ilmu politik, dimana kasus pengeboman hotel J.W Marriot dan Rizt Carlton yang dilakukan teroris berkaitan dengan politik.

Penangkapan teroris di daerah Bekasi menguak semua tentang rencana pembunuhan Presiden SBY yang rencananya dilakukan pada bulan Agustus 2010 serta ditemukannya bukti foto presiden Susilo Bambang Yudhoyono sebagai sasaran latihan tembak para teroris, membuktikan bahwa serangan teroris tersebut disinyalir ada nuansa politik.

Dalam sebuah berita, banyaknya narasumber yang ditampilkanmembuatberitatersebutsemakin menarik untuk dibaca. Narasumber yang banyak dipakai oleh SKH Kompas adalah kombinasi. Kombinasi narasumber yang banyak dipakai 
adalah kombinasi Pemerintah Indonesia dan saksi. Pemakaian narasumber kombinasi ini dilakukan SKH Kompas untuk menunjukkan bahwa dalam menyajikan suatu berita SKH Kompas selalu berusaha cover both side. Narasumber merupakan faktor penting karena tanpa narasumber berita yang disampaikan menjadi kurang akurat. Hal ini dikarenakan pernyataan dari narasumber menjadi pendukung fakta yang ada di lapangan. Oleh karena itu, dalam menentukan narasumber, media harus selektif yaitu memilih narasumber yang berkompeten dalam hal tersebut.

Banyaknya kombinasi Pemerintah Indonesia dengan saksi yang muncul menunjukkan bahwa dalam mencari para pelaku teroris, membutuhkan saksi agar tidak salah tangkap serta untuk mendapatkan tempat persembunyian. Masyarakat memang harus turut campur dalam penanganan pemberantasan teroris. Sedangkan pemerintah Indonesia adalah pihak yang berwenang menangkap para pelaku teroris di Indonesia. SKH Kompas dalam hal ini ingin menunjukkan bahwa dalam pemberantasan teroris di Indonesia memerlukan kerjasama antara pemerintah dan masyarakat.

SKH Kompas sudah menunjukkan keseimbangannya dalam menyajikan berita tentang kasus terorisme ini. SKH Kompas banyak menyajikan berita dari dua sisi. Dalam hal ini SKH kompas tidak hanya memberitakan para pelaku terorisme saja, para korban bom dan pihak yang dirugikan dalam aksi terorisme juga diberitakan maka dari pada itu SKH kompas melakukan liputan dua sisi untuk mencari keseimbangan berita atau tidak berat sebelah.

SKH Kompas lebih banyak memberi informasi dan argumen dari narasumber yang berkompeten. Argumentasi dari narasumber disini adalah pemikiran dan pernyataan narasumber mengenai masalah tersebut. Argumentasi dari narasumber disini digunakan untuk memberi penjelasan kepada pembaca mengenai masalah ini. Sifat berita informatif disini digunakan untuk menunjukkan efek atau dampak yang ditimbulkan oleh ledakan bom di Hotel J.W Marriot dan Ritz Carlton. Hal ini tentunya akan memberikan informasi kepada khalayak luas secara lebih lengkap sehingga fungsi media sebagai sumber informasi dapat terlaksana.

SKH Kompas dalam menyajikan suatu berita lebih banyak berorientasi pada psikologis. Hal ini menunjukkan bahwa dalam mendeskripsikan suatu fakta dan memberikan informasi SKH Kompas selalu memperkuatnya dengan argumen dari narasumber yang berkompeten. Hal ini membuktikan bahwa SKH Kompas tetap menjaga kredibilitasnya sebagai salah satu surat kabar tersohor di Indonesia, jadi berita yang diterbitkan bukanlah berita yang hanya sembarangan mengambil pernyataan dari narasumber untuk dijadikan sebuah berita.

Tema berita yang banyak diangkat adalah mengenai proses pencarian pelaku. SKH Kompas lebih banyak menyoroti persoalan tersebut karena setelah kasus ini mencuat, banyak reaksi dari negara-negara lain, karena kasus terorisme ini merupakan kejahatan Internasional. Berbagai upaya kerjasama telah dilakukan antara lain dengan beberapa negara seperti Thailand, Singapura, Malaysia, Philipina, dan Australia, bahkan negara-negara seperti Amerika Serikat, Inggris, Kanada, Perancis, dan Jepang. Masalah ekstradisi antara pemerintah Singapura dan Indonesia belum terealisasi. Implikasi terhadap Persatuan dan Kesatuan Bangsa. Kekhawatiran masyarakat terhadap bahaya teror bom masih ada. Hal ini apabila tidak segera ditangani secara bijak akan mempengaruhi roda perekonomian. Di sisi lain, penindakan, penangkapan atau pemeriksaan oleh aparat terhadap siapa dan organisasi yang ada di masyarakat perlu sikap hati-hati, agar tidak menimbulkan sentimen negatif di kalangan masyarakat itu sendiri, pemerintah diangapnya diskriminatif atau muncul berbias pada permasalahan baru yang bernuansa SARA. Selain itu, nantinya ditakutkan munculnya generasi teroris yang baru jika pelakunya tidak di tangkap. 
SKH Kompas juga banyak mengangkat tema dampak pengeboman. SKH Kompas disini ingin memberi informasi kepada masyarakat tentang jumlah korban yang jatuh dan dampak apa saja yang terjadi. Selain untuk mengetahui mengenai jumlah korban yang jatuh, pembaca dapat mengetahui sejauh mana Pemerintah Indonesia berusaha mengatasi masalah tersebut dan bagaimana tindakan pemerintah Indonesia terhadap para korban.

Dalam menulis berita, sebuah media harus bersikap netral dalam menulis informasi tersebut. Sebagai media yang bertugas sebagai pemberi informasi dan jembatan aspirasi masyarakat, dalam kasus ini SKH Kompas dalam melakukan penulisan berita bersikap netral, tanpa memojokan salah satu pihak.

\section{Simpulan}

Media massa berperan penting pada saat terjadinya kasus ledakan bom yang dilakukan oleh teroris. Media massa menjalankan tugas untuk menyampaikan informasi kepada khalayak dan mengontrol jalannya pemulihan pasca terjadinya peledakan. Media langsung atau tidak, ikut ambil bagian dalam memulihkan trauma masyarakat, mengembalikan kondisi seperti semula atas bencana tersebut.

SKH Kompas sebagai salah satu surat kabar harian berskala nasional sudah menyajikan porsi yang cukup untuk berita kasus ledakan bom di Hotel J.W Marriot dan Ritz Carlton, hal ini menyebabkan peristiwa ini mendapat perhatian dan tanggapan dari banyak pihak. Kasus ledakan bom di Hotel J.W Marriot dan Ritz Carlton terjadi pada tanggal 17 Juli 2009. Peran media dalam kasus ini adalah memberikan informasi dalam pemberitaanya. Selain masyarakat mengetahui bagaimana Densus 88 mengusut kasus terorisme yang terjadi hal ini juga mengisyaratkan bahwa pemerintahan dan jajarannya berusaha membersihkan negara Indonesia dari pelaku terorisme.

\section{Daftar Pustaka}

Afifi, Subhan. (2004). Buku Ajar Sistem Perbandingan Media Massa. Yogyakarta: UPN "Veteran" Yogyakarta

Hendropriyono, A.M. (2009). Fundamentalis Kristen, Yahudi, Islam. Jakarta: PT Kompas Media Nusantara.

Krippendorf, K. (1993). Analisis Isi: Pengantar Teori\&Metodologi. Jakarta: Raja Grafindo Persada.

Laquer, Walter. (2005). Fanatisme \& Senjata Pemusnah Massal. Yogyakarta: Kreasi Wacana.

McQuail, Dennis. (1987). Teori Komunikasi Massa Suatu Pengantar. Jakarta: Erlangga.

Oetama, Jakob. (2001). Pers Indonesia: Berkomunikasi dalam Masyarakat Tidak Tulus. Jakarta: Penerbit Buku Kompas.

Susilastuti, Dkk. (2006). Buku ajar Komunikasi Politik. Yogyakarta: UPN "Veteran" Yogyakarta. 